\title{
A two-channel, tunable diode laser-based hygrometer for measurement of water vapor and cirrus cloud ice water content in the upper troposphere and lower stratosphere
}

\author{
T. D. Thornberry ${ }^{1,2}$, A. W. Rollins ${ }^{1,2}$, R. S. Gao ${ }^{1}$, L. A. Watts ${ }^{1,2}$, S. J. Ciciora ${ }^{1}$, R. J. McLaughlin ${ }^{1,2}$, and D. W. Fahey ${ }^{1,2}$ \\ ${ }^{1}$ NOAA ESRL Chemical Sciences Division, Boulder, Colorado, USA \\ ${ }^{2}$ Cooperative Institute for Research in Environmental Sciences, University of Colorado, Boulder, Colorado, USA
}

Correspondence to: T. D. Thornberry (troy.thornberry@noaa.gov)

Received: 19 July 2014 - Published in Atmos. Meas. Tech. Discuss.: 11 August 2014

Revised: 12 November 2014 - Accepted: 25 November 2014 - Published: 12 January 2015

\begin{abstract}
The recently developed NOAA Water instrument is a two-channel, closed-path, tunable diode laser absorption spectrometer designed for the measurement of upper troposphere/lower stratosphere water vapor and enhanced total water (vapor + inertially enhanced condensed phase) from the NASA Global Hawk unmanned aircraft system (UAS) or other high-altitude research aircraft. The instrument utilizes wavelength-modulated spectroscopy with second harmonic detection near $2694 \mathrm{~nm}$ to achieve high precision with a $79 \mathrm{~cm}$ double-pass optical path. The detection cells are operated under constant temperature, pressure, and flow conditions to maintain a constant sensitivity to $\mathrm{H}_{2} \mathrm{O}$ independent of the ambient sampling environment. An onboard calibration system is used to perform periodic in situ calibrations to verify the stability of the instrument sensitivity during flight. For the water vapor channel, ambient air is sampled perpendicular to the flow past the aircraft in order to reject cloud particles, while the total water channel uses a heated, forwardfacing inlet to sample both water vapor and cloud particles. The total water inlet operates subisokinetically, thereby inertially enhancing cloud particle number in the sample flow and affording increased cloud water content sensitivity. The NOAA Water instrument was flown for the first time during the second deployment of the Airborne Tropical TRopopause EXperiment (ATTREX) in February-March 2013 on the NASA Global Hawk UAS. The instrument demonstrated a typical in-flight precision $(1 \mathrm{~s}, 1 \sigma)$ of better than 0.17 parts per million (ppm, $10^{-6} \mathrm{~mol} \mathrm{~mol}^{-1}$ ), with an overall $\mathrm{H}_{2} \mathrm{O}$ vapor measurement uncertainty of $5 \% \pm 0.23 \mathrm{ppm}$. The inertial enhancement for cirrus cloud particle sampling under AT-
\end{abstract}

TREX flight conditions ranged from 33 to 48 for ice particles larger than $8 \mu \mathrm{m}$ in diameter, depending primarily on aircraft altitude. The resulting ice water content detection limit $(2 \sigma)$ was $0.023-0.013 \mathrm{ppm}$, corresponding to approximately $2 \mu \mathrm{g} \mathrm{m}^{-3}$, with an estimated overall uncertainty of $20 \%$.

\section{Introduction}

Water in the upper troposphere and lower stratosphere (UT/LS) plays an important role in Earth's climate system through aspects of radiative transfer, cirrus cloud formation, and stratospheric ozone chemistry (Kirk-Davidoff et al., 1999; Forster and Shine, 2002; Solomon et al., 2010). The dominant transport of $\mathrm{H}_{2} \mathrm{O}$ into the stratosphere occurs in the tropics and is controlled to first order by the cold temperatures of the tropical tropopause (Liu et al., 2010; Schoeberl and Dessler, 2011; Randel and Jensen, 2013). However, uncertainty remains in both the microphysics of dehydration in the tropical tropopause layer (TTL) and the potential contributions of other processes (e.g., overshooting convection, transport from the extratropics) to the water budget of the lower stratosphere (Sherwood and Dessler, 2001; Fueglistaler et al., 2009; Randel and Jensen, 2013). Cirrus clouds occur with high frequency and large spatial extent in the TTL, and those occurring near the thermal tropopause facilitate the final dehydration of stratospherebound air parcels. The net role of TTL cirrus clouds in the climate system and how cloud effects may change as the climate changes remains uncertain (Dessler, 2010; Zelinka 
and Hartmann, 2011; Randel and Jensen, 2013). Further accurate measurements of water vapor in the tropical UT/LS are needed to improve understanding of the dynamical and microphysical processes that control the dehydration of air transported into the stratosphere. In contrast to water vapor, fewer in situ measurements of cirrus ice water content (IWC) exist for the UT/LS. IWC is an important metric for estimating both the radiative impact of cirrus clouds and their role in the dehydration of tropospheric air in the TTL.

A number of different in situ measurement techniques have been used to measure water vapor in the UT/LS. These include chilled-mirror hygrometry (Brewer et al., 1948; Mastenbrook and Oltmans, 1983; Vömel et al., 2007), Lyman- $\alpha$ photofragment fluorescence (Kley and Stone, 1978; Weinstock et al., 1994; Zöger et al., 1999), both open- and closedpath tunable diode laser (TDL) absorption spectroscopy (May, 1998; Diskin et al., 2002; Buchholz et al., 2013; Sargent et al., 2013), and chemical ionization mass spectrometry (Thornberry et al., 2013; Kaufmann et al., 2014).

Persistent disagreements among collocated measurements of $\mathrm{H}_{2} \mathrm{O}$ in the UT/LS have produced uncertainties in our understanding of the cirrus cloud microphysics that control dehydration of tropospheric air in the tropical tropopause region and determine the amount of $\mathrm{H}_{2} \mathrm{O}$ that reaches the lower stratosphere (Kley et al., 2000; Jensen et al., 2005; Peter et al., 2006; Weinstock et al., 2009). These disagreements among collocated in situ measurements have prompted community efforts to determine the sources of error in the $\mathrm{H}_{2} \mathrm{O}$ measurements, including the chamber-based AquaVIT-1 intercomparison in 2007 (Fahey et al., 2014) and a recent in situ intercomparison during the Mid-latitude Airborne Cloud Properties EXperiment (MACPEX) in 2011 (Rollins et al., 2014). In the AquaVIT-1 intercomparison, a number of the primary UT/LS in situ $\mathrm{H}_{2} \mathrm{O}$ instruments reported values that generally agreed within $20 \%$ at mixing ratios down to 1 part per million (ppm, $10^{-6} \mathrm{~mol} \mathrm{~mol}^{-1}$ ) under static conditions similar to those in the TTL. This was a significant improvement over the $30-100 \%$ differences observed at low mixing ratios in a number of previous UT/LS field measurements (Kley et al., 2000; Jensen et al., 2005; Weinstock et al., 2009), suggesting that additional factors affect instrument performance when operating on aircraft in field campaigns. During the MACPEX campaign, the observed differences among instruments at low mixing ratios were typically within $20 \%$, similar to the AquaVIT- 1 results. A careful analysis of the data found that all of the instruments were potentially affected by variable background artifacts that became significant at mixing ratios below $10 \mathrm{ppm}$ (Rollins et al., 2014). Variations at this level in long-term data sets are sufficient to preclude the early identification of trends in UT/LS $\mathrm{H}_{2} \mathrm{O}$ that are predicted to occur with changes in Earth's climate (Kley et al., 2000; Fueglistaler et al., 2013).

Measurement of TTL cirrus IWC is even more challenging because it combines the issues of water vapor measurement at low mixing ratios with the need to characterize the sam- pling efficiency of cloud particles. A number of different instruments have been developed and deployed for cirrus IWC determination, using both TDL (Davis et al., 2007a; Dorsi et al., 2014) and Lyman- $\alpha$ (Brown and Francis, 1995; Weinstock et al., 2006a; Schiller et al., 2008) detection. Typically these instruments measure the sum of water vapor and evaporated/sublimated condensed-phase water, and rely on a second instrument to measure only water vapor in order to derive a value for the IWC. The counterflow virtual impactor (CVI) instrument described by Twohy et al. (1997) eliminates this need by inertially separating the cloud particles into a dry synthetic air stream, allowing the particles to sublimate, and measuring the resulting water vapor. The CVI produces a lower-limit size cut-off for sampled particles and therefore generally will not afford detection of the IWC of sufficiently small ice crystals. Total water sampling inlets are operated either isokinetically (Weinstock et al., 2006a, b) to simplify the characterization of the particle sampling, or subisokinetically (Davis et al., 2007a; Schiller et al., 2008) to enhance the particle concentration sampled into the instrument for improved IWC sensitivity. Davis et al. (2007b) report on a comparison of three in situ IWC measurements made during the NASA Midlatitude Cirrus Experiment in 2004. The measurements demonstrated reasonable agreement at high IWC loadings, but the differences were significant at values below $5 \mathrm{mg} \mathrm{m}^{-3}$, a value more than an order of magnitude larger than typically found in TTL cirrus (Davis et al., 2007b; Schiller et al., 2008).

To take advantage of the TTL sampling capabilities of the NASA Global Hawk UAS platform, we have developed a new, compact, two-channel instrument for the simultaneous measurement of water vapor and total water in the UT/LS, and integrated it onboard the Global Hawk during the recent NASA Airborne Tropical TRopopause EXperiment (ATTREX) mission. Here we describe details of the instrument design and validation, and present instrument performance from recent measurements in the UT/LS obtained during ATTREX.

\section{The NOAA Water instrument}

\subsection{General description}

The NOAA Water instrument is a two-channel, closed-path, TDL absorption spectrometer for the measurement of UT/LS water vapor (WV) and enhanced total water (eTW, vapor + inertially enhanced condensed phase) from the NASA Global Hawk UAS or other high-altitude research aircraft. The instrument utilizes wavelength modulation spectroscopy with second harmonic (2f) detection at a wavelength near $2694 \mathrm{~nm}$ to achieve high sensitivity and precision at low mixing ratios. The instrument is calibrated on the ground by comparison to a reference chilled-mirror hygrometer (model 373LX, MBW Calibration Ltd., Wettingen, Switzerland) and the stability of 


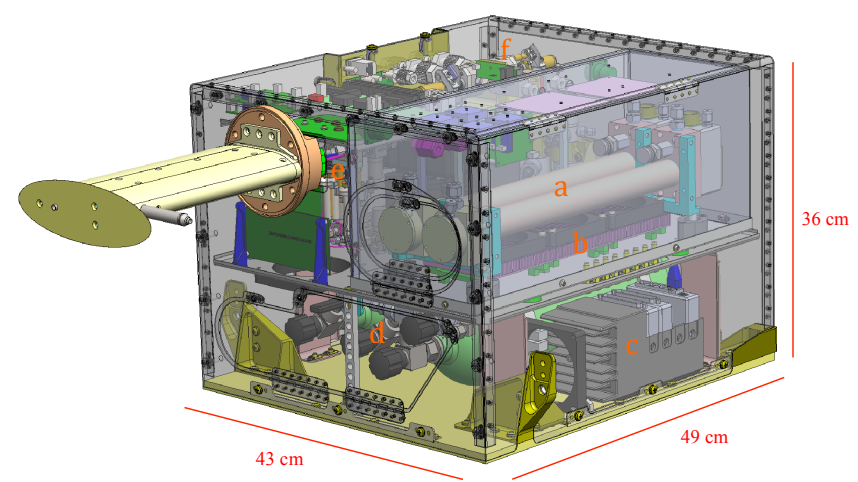

Figure 1. Schematic of the NOAA Water instrument showing the inlet pylon, optics sub-enclosure, and some of the principal instrument components: (a) absorption cells within the optics subenclosure, (b) optical sub-enclosure heaters, (c) CompactRIO data system, (d) gas bottles, (e) sample mass flow control valves, and (f) cell pressure control valves. The enclosure structure and pylon are fabricated from aircraft-grade aluminum.

the calibration during flight is assessed periodically by addition of water vapor to one of the channels. The absorption cells are operated under conditions of constant pressure, temperature, and flow to maintain constant sensitivity independent of pressure and temperature changes in the payload compartment or in the ambient sampling environment. This approach eliminates the need for highly accurate knowledge of the pressure- and temperature-dependent spectral line parameters and consequently complex data reduction in exchange for a reduced absolute absorption signal that results from operating the cells at pressures below the lowest ambient pressure encountered in flight.

A summary of the instrument physical and performance specifications appears in Table 1 . The main instrument enclosure (Fig. 1) measures $49 \mathrm{~cm} \times 43 \mathrm{~cm} \times 36 \mathrm{~cm}$ and houses the optical absorption cells, calibration system, custom electronics, and data acquisition and control computer. The inlet pylon is attached to an interface flange at the fuselage surface and extends outside the fuselage perpendicular to the free-stream flow. Two small scroll pumps, their associated controllers, and a 24 VDC power supply are located external to the main instrument enclosure. The total instrument mass, including pumps and inlet pylon, is $40 \mathrm{~kg}$. During flight, typical power consumption is $70 \mathrm{~W}$ of DC $(28 \mathrm{~V})$ and $400 \mathrm{~W}$ of $\mathrm{AC}(120 \mathrm{~V}, 400 \mathrm{~Hz})$. The AC power draw varies depending on the power required by the heaters used to maintain instrument component temperatures.

\subsection{Sample flow system}

A schematic of the instrument flow system is shown in Fig. 2. Sample flow through the instrument is produced by a pair of small scroll pumps (model V12H20N2.5, Air Squared Inc., Broomfield, CO, USA). The sample mass flow
Table 1. NOAA Water instrument specifications.

\begin{tabular}{|c|c|c|}
\hline $\begin{array}{l}\text { Size } \\
\text { Mass } \\
\text { Power } \\
\text { Data rate }\end{array}$ & \multicolumn{2}{|c|}{$\begin{array}{c}49 \mathrm{~cm} \times 43 \mathrm{~cm} \times 36 \mathrm{~cm} \\
40 \mathrm{~kg} \\
70 \mathrm{~W} \mathrm{DC}, 400 \mathrm{~W} \mathrm{AC} \\
1 \mathrm{~Hz}\end{array}$} \\
\hline & WV & TW \\
\hline $\begin{array}{l}\text { Accuracy } \\
\text { Precision }(1 \mathrm{~s}, 1 \sigma) \\
\text { Uncertainty }(1 \mathrm{~s}) \\
\text { IWC uncertainty (1 s) }\end{array}$ & $\begin{array}{l}5 \% \pm 0.15 \mathrm{ppm} \\
0.17 \mathrm{ppm} \\
5 \% \pm 0.23 \mathrm{ppm}\end{array}$ & $\begin{array}{l}6 \% \pm 0.20 \mathrm{ppm} \\
0.25 \mathrm{ppm} \\
6 \% \pm 0.32 \mathrm{ppm} \\
15-30 \%\end{array}$ \\
\hline
\end{tabular}

through each channel is controlled using a custom butterfly valve (BV) based on the design described by Gao et al. (1999) and similar to those used previously with the NOAA CIMS $\mathrm{H}_{2} \mathrm{O}$ instrument (Thornberry et al., 2013). The $\mathrm{BV}$ is located in the inlet line upstream of the absorption cell and is servo-controlled by a mass flow meter (MFM, model D6F-03A3, Omron Corp., Kyoto, Japan) located in the exhaust line from the absorption cell. The mass flow through each cell was maintained at 600 standard $(273.15 \mathrm{~K}$, $1013.25 \mathrm{hPa}$ ) $\mathrm{cm}^{3} \mathrm{~min}^{-1}$ ( $\mathrm{sccm}$ ). The flow value was chosen to be as large as possible, within the capacity of the vacuum pumps, in order to reduce the potential for hysteresis arising from the adsorption/desorption of water to inlet tubing and cell surfaces. The pressure in each absorption cell is controlled using a second BV located in the exhaust line from the cell, immediately downstream of the sample flow MFM, which is servo-controlled by a pressure sensor (model 19C015PA4K, Honeywell Sensing and Control, Minneapolis, MN, USA) located at the laser/detector end of the absorption cell. The absorption cell pressures were set to 45 and $50 \mathrm{hPa}$ in the WV and TW channels, respectively, in order for the pressures to be sufficiently lower than the inlet sampling pressures at the highest flight altitudes for Global Hawk operation to enable cell pressures and flows to be held constant at all aircraft flight levels. The control pressure difference between the two channels is due to a combination of the additional ram pressure at the opening of the forwardfacing TW inlet and the reduced sampling pressure at the side-facing opening of the WV inlet.

\subsection{Absorption cells}

The absorption cells for the NOAA Water instrument were designed and manufactured by Port City Instruments (Wilmington, NC, USA). A schematic of an optical absorption cell is shown in Fig. 3. Each cell consists of a $35 \mathrm{~cm}$ long, $1.9 \mathrm{~cm}$ ID $(3.2 \mathrm{~cm} \mathrm{OD})$ Ni-plated aluminum cylinder with a Ni-plated aluminum block housing the inlet port and a gold mirror on one end and another block housing the outlet port, laser, detector, and pressure port on the other. This singlereflection arrangement produces a $78.6 \mathrm{~cm}$ round-trip optical 


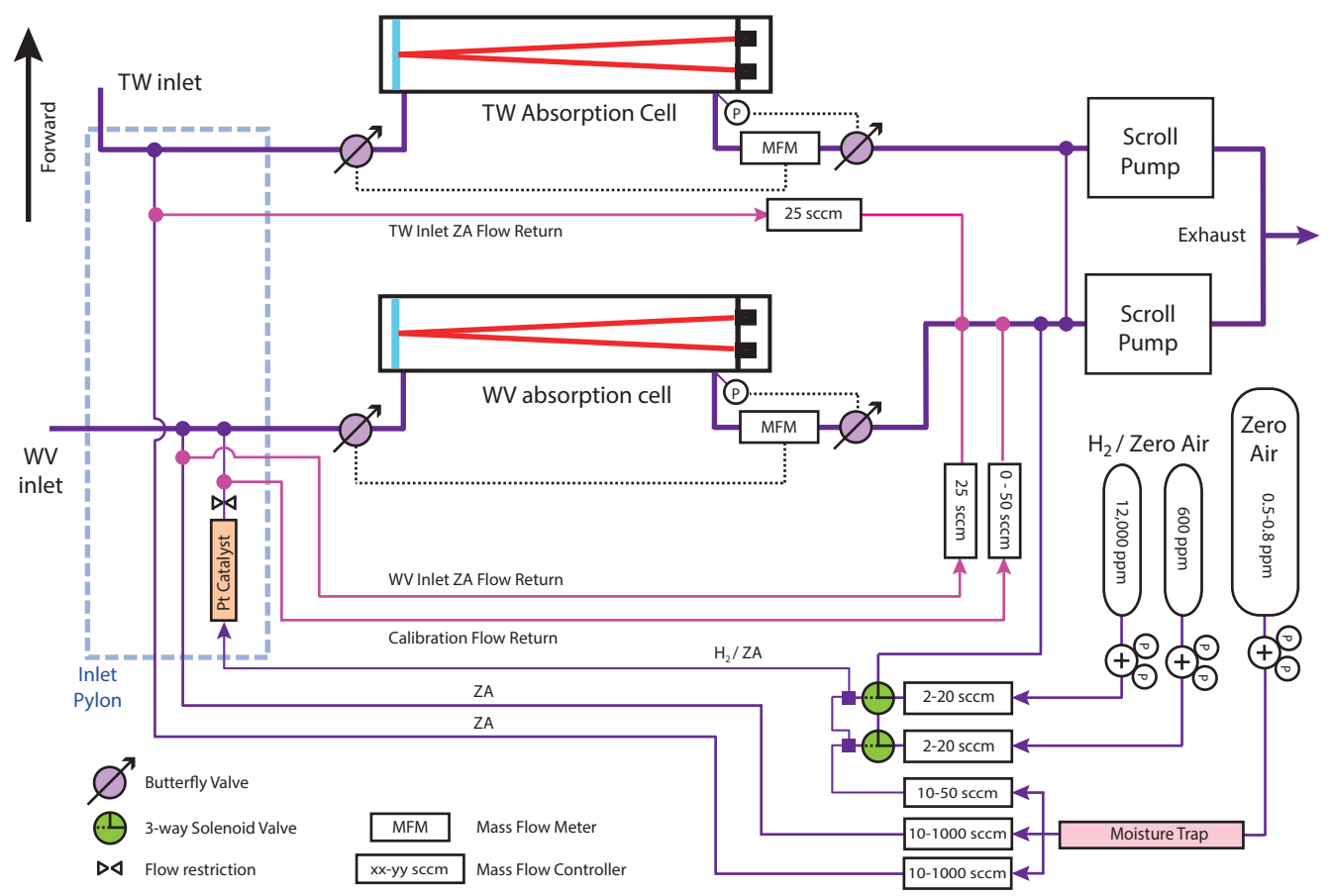

Figure 2. Schematic of the NOAA Water instrument showing the components of the dual-channel flow system. The custom butterfly valves located upstream and downstream of each cell are used to control the mass flow (upstream) and pressure (downstream) in the optical cells to constant values independent of variations in sampling pressure as the aircraft changes altitude. The numbers in the mass flow controller symbols indicate the flow value or range used during flight operation.

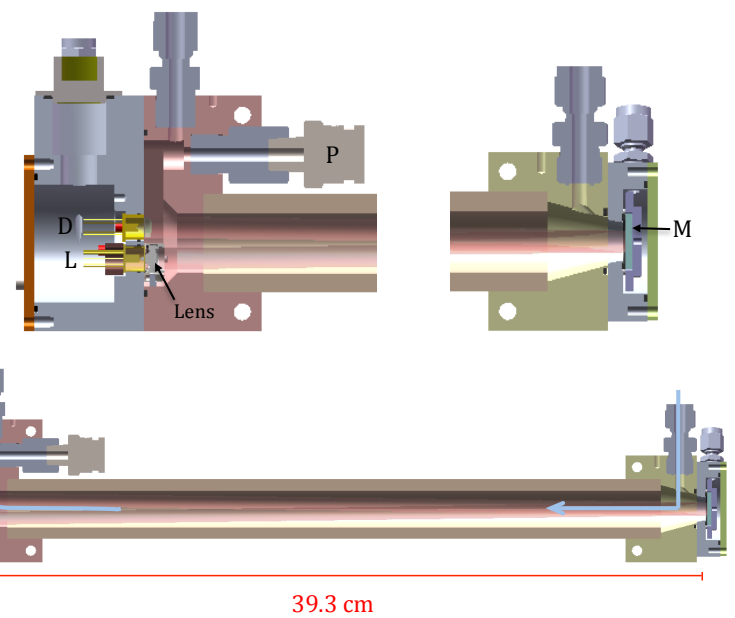

Figure 3. Schematic of a NOAA Water instrument optical absorption cell. Arrows indicate the direction of flow through the cell. The laser (L), detector (D), collimating lens assembly (Lens), and pressure transducer $(\mathrm{P})$ are visible in the detail on the left (outlet), and the mirror (M) assembly is indicated in the detail on the right (inlet).

absorption path length. The internal cell volume is approximately $120 \mathrm{~cm}^{3}$, yielding a sample residence time of less than $0.52 \mathrm{~s}$ at a flow rate of $600 \mathrm{sccm}$, cell pressure of $50 \mathrm{hPa}$, and cell temperature of $40^{\circ} \mathrm{C}$. The inlet, outlet, and pressure ports were designed for O-ring face-seal fittings (VCO, Swagelok Inc., Solon, OH, USA) to minimize potential for leaks into the cells.

In order to thermally stabilize the optical cavity and minimize the migration of interference fringes through the spectrum, the absorption cells are housed in a temperaturecontrolled sub-enclosure within the overall instrument enclosure. The temperature of the sub-enclosure is stabilized by controlling the air temperature within the sub-enclosure by means of forced circulation of air over temperaturecontrolled heat sinks and by separately controlling the temperatures of the six individual aluminum panels comprising the sub-enclosure. Three thermistors, one at each end and one at the mid-point of the cell, are used to monitor the thermal stability of the absorption cells.

The laser and detector are mounted directly into the block at the outlet end of the absorption cell to minimize the potential for any volume in the optical path that is not actively swept by the sample flow through the cell. A lens mounted in an open structure in front of the laser is used to collimate the beam. The gold mirror is sealed against the inlet end of the absorption cell using an O-ring face seal. Four small screws in the mirror assembly that compress the mirror against the O-ring allow for adjustment of the mirror angle for alignment of the laser beam. 


\subsection{Lasers and detectors}

The lasers used in the instrument are distributed feedback (DFB) lasers (nanoplus GmbH, Gerbrunn, Germany) mounted on thermoelectric coolers (TEC) and sealed in TO5 packages with antireflection-coated, wedged windows. The laser packages are evacuated and backfilled with $\mathrm{N}_{2}$ at 1 bar pressure and contain less than $30 \mathrm{ppm}$ residual $\mathrm{H}_{2} \mathrm{O}$. The sealed optical path between the diode facet and TO5 package window is $0.5 \mathrm{~mm}$, resulting in a maximum optical depth due to residual $\mathrm{H}_{2} \mathrm{O}$ in the laser packages equivalent to $0.375 \mathrm{ppm}$ in the sample cell at $50 \mathrm{hPa}$. Lasing threshold current and tuning characteristics are inherently variable with DFB lasers; however the useful tunable range accessible in a single current scan for the lasers used here was typically $2-3 \mathrm{~cm}^{-1}$.

The InAs detectors (J12TE1-37S-R01M, Teledyne Judson Technologies, Montgomeryville, PA, USA) used are mounted on TECs in sealed packages. These packages were evacuated, baked, and backfilled with $\mathrm{N}_{2}$ during fabrication to $50 \mathrm{hPa}$ with a maximum of $5 \mathrm{ppm}$ residual $\mathrm{H}_{2} \mathrm{O}$. The optical path between the photodiode and window is approximately $2 \mathrm{~mm}$, resulting in a signal from trapped water equivalent to less than 0.014 ppm water in the detection cell.

For measurement of $\mathrm{H}_{2} \mathrm{O}$, a pair of absorption lines near $2694 \mathrm{~nm}$ was identified from the HITRAN 2008 database (Rothman et al., 2009). To access the selected $\mathrm{H}_{2} \mathrm{O}$ absorption features, the laser TEC temperatures are set to values that yield output near the target wavelength for each individual laser and the laser drive currents are ramped to scan the lasers across a spectral range of approximately $1 \mathrm{~cm}^{-1}$. The primary absorption line used to detect low mixing ratios of $\mathrm{H}_{2} \mathrm{O}$ is from the asymmetric stretch mode $((0,0,1) \leftarrow$ $(0,0,0))$ at $3712.20 \mathrm{~cm}^{-1}(2693.82 \mathrm{~nm})$ with a line strength of $1.49 \times 10^{-19} \mathrm{~cm}^{2}$ molecule ${ }^{-1} \mathrm{~cm}^{-1}$. This line is approximately an order of magnitude stronger than strong lines in the $\mathrm{H}_{2} \mathrm{O}$ overtone/combination band near $1400 \mathrm{~nm}$ that have typically been used for UT/LS $\mathrm{H}_{2} \mathrm{O}$ measurement. A weaker line at $3711.88 \mathrm{~cm}^{-1}(2694.06 \mathrm{~nm})$ due to the symmetric stretching mode $((1,0,0) \leftarrow(0,0,0))$ with a line strength of $4.41 \times 10^{-21} \mathrm{~cm}^{2}$ molecule ${ }^{-1} \mathrm{~cm}^{-1}$ is used at higher $\mathrm{H}_{2} \mathrm{O}$ mixing ratios to provide a linear response up to and exceeding $2000 \mathrm{ppm}$. Two prominent $\mathrm{CO}_{2}$ absorption lines at $3711.62 \mathrm{~cm}^{1}(2694.24 \mathrm{~nm})$ and $3711.75 \mathrm{~cm}^{-1}(2694.15 \mathrm{~nm})$ also fall within the scan window and could potentially be used for additional instrument diagnostics.

The $1 \mathrm{~cm}^{-1}$ spectral sweep is performed at $10 \mathrm{~Hz}$ and the spectra are coaveraged to produce $1 \mathrm{~s}$ data. Improved precision is achieved by use of $2 \mathrm{f}$ detection, which is employed by adding a $30 \mathrm{kHz}$ sine wave modulation to the diode laser current ramp, producing a $0.08 \mathrm{~cm}^{-1}$ modulation depth of the scan, and demodulating the signal from the photodiode detector at $60 \mathrm{kHz}$. DC spectra are concurrently measured by passing the detector signal through a low-pass filter to remove the modulation. Figure 4 presents the spectral region scanned showing calculated transmission through the optical
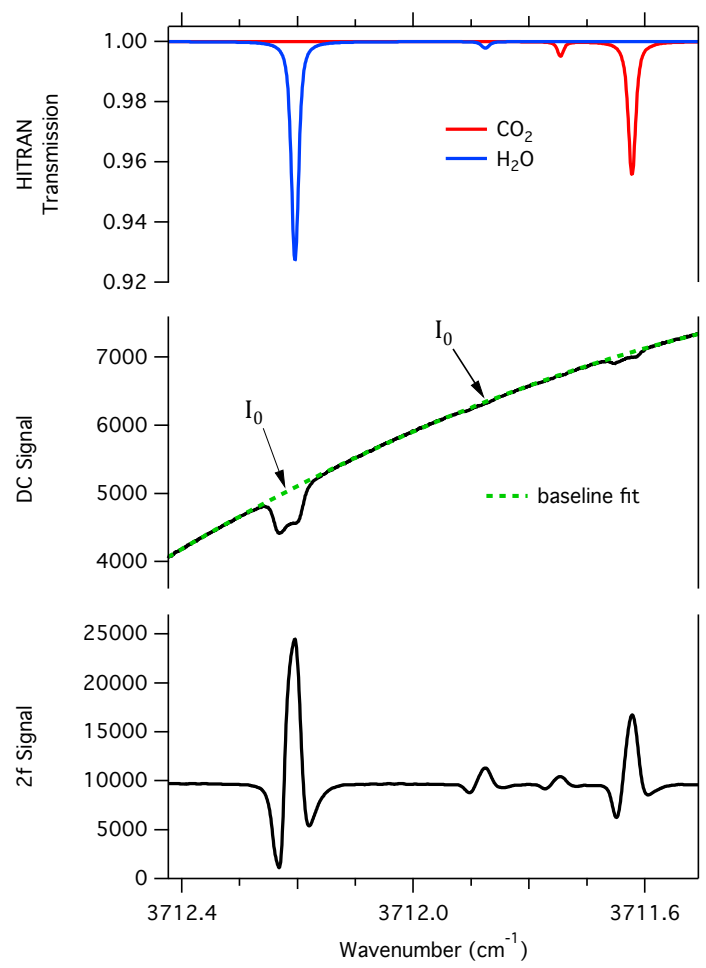

Figure 4. Top: HITRAN calculation of transmission through the detection cell with 100 ppm $\mathrm{H}_{2} \mathrm{O}$ (blue) and 370 ppm $\mathrm{CO}_{2}$ (red). Middle: $1 \mathrm{~s}$ coaveraged DC spectrum in the WV channel from the final descent on 27 February 2013 at an ambient $\mathrm{H}_{2} \mathrm{O}$ mixing ratio of approximately $100 \mathrm{ppm}$. The green dashed line is the polynomial fit to the baseline for determination of the $\mathrm{I}_{0}$ values at the strong and weak $\mathrm{H}_{2} \mathrm{O}$ absorption lines. Bottom: corresponding $1 \mathrm{~s}$ coaveraged $2 \mathrm{f}$ spectrum. Note that the scan is plotted as it is recorded in time and the wave number scale decreases from left to right.

cell using line parameters from the HITRAN 2008 database along with the measured DC and $2 \mathrm{f}$ spectra of ambient air containing $100 \mathrm{ppm} \mathrm{H}_{2} \mathrm{O}$. The strong and weak line $2 \mathrm{f}$ signals are measured as the peak-to-peak amplitude in the spectrum in a defined window around each line. The asymmetry observed in the peaks in the $2 \mathrm{f}$ spectrum arises from contributions to the second harmonic signal from the first and third harmonics due to co-modulation of laser intensity with the applied wavelength modulation (Kluczynski and Axner, 1999). To account for variations in laser power that would affect the instrument sensitivity, the $2 \mathrm{f}$ signals are normalized to the laser power at each spectral feature (N2f: $2 \mathrm{f}$ peak-topeak amplitude/laser power at line center) before calculating water mixing ratios. Laser power at the center of each line is determined from a polynomial fit to the corresponding DC spectrum baseline.

\subsection{Inlets}

The inlets for the two channels of the NOAA Water instrument are housed in an airfoil-shaped pylon assembly that ex- 


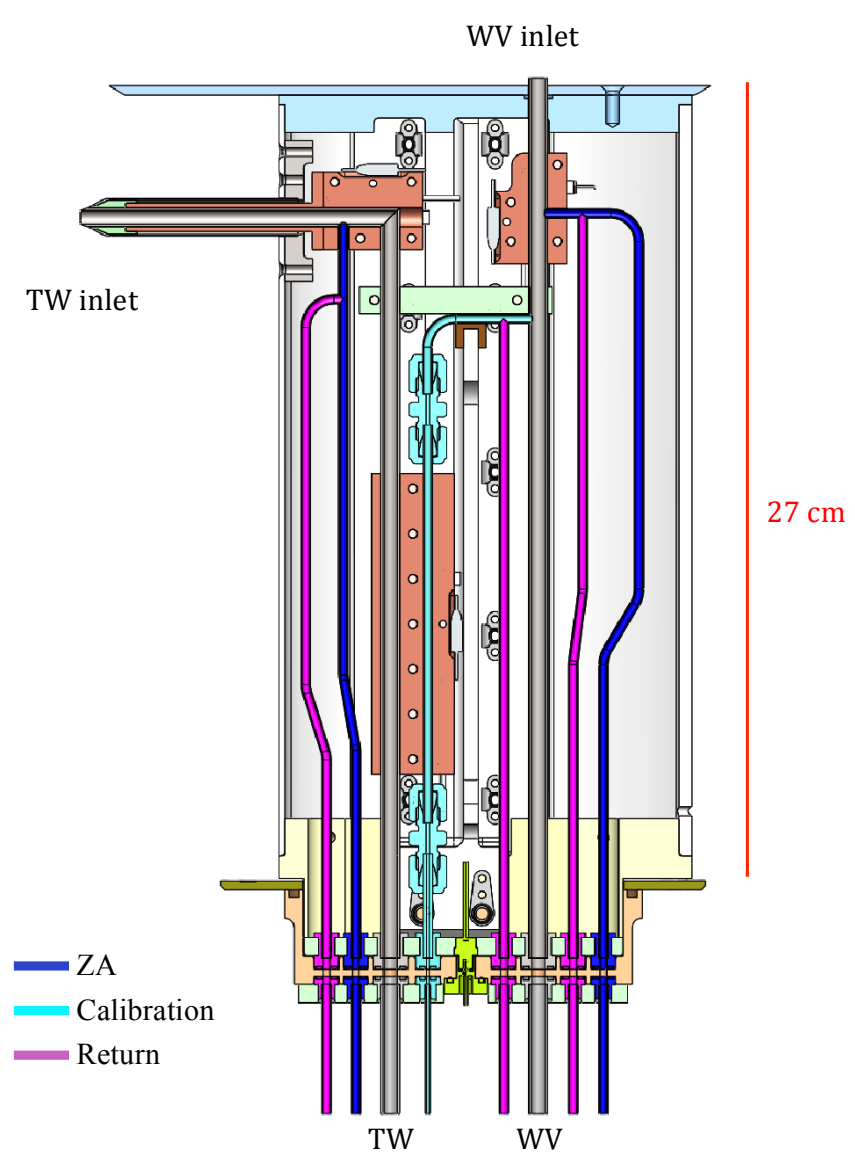

Figure 5. Schematic of the NOAA Water instrument inlet pylon showing the WV and TW sample inlet tubes, the inlet line and catalyst heater blocks (orange), the zero air (ZA) delivery lines (blue) to each inlet, the Pt catalyst and calibration delivery line (cyan) to the WV inlet, and the ZA and calibration return lines (magenta).

tends $27 \mathrm{~cm}$ perpendicular to the skin of the aircraft in order to sample in the free-stream flow around the aircraft. The pylon is $14 \mathrm{~cm}$ wide (fore-aft) and $3.5 \mathrm{~cm}$ thick. The major axis of the airfoil is oriented parallel to the aircraft longitudinal axis (i.e., no offset angle). A cross section of the inlet pylon is presented in Fig. 5 showing the arrangement of the inlet components and calibration tubing. A photograph of the instrument installed onboard the NASA Global Hawk during ATTREX appears in Fig. 6. Gas flows between the inlet pylon and the instrument pass through custom O-ring face-seal fittings at the interface flange. This design provides a good, reproducible seal while allowing the inlet pylon to be easily installed and removed when necessary for accessing the instrument.

\subsubsection{Water vapor inlet}

The sampling point for the WV channel is located at the end of the inlet pylon, oriented perpendicular to the flow past the aircraft (Fig. 5). This sampling arrangement, combined with

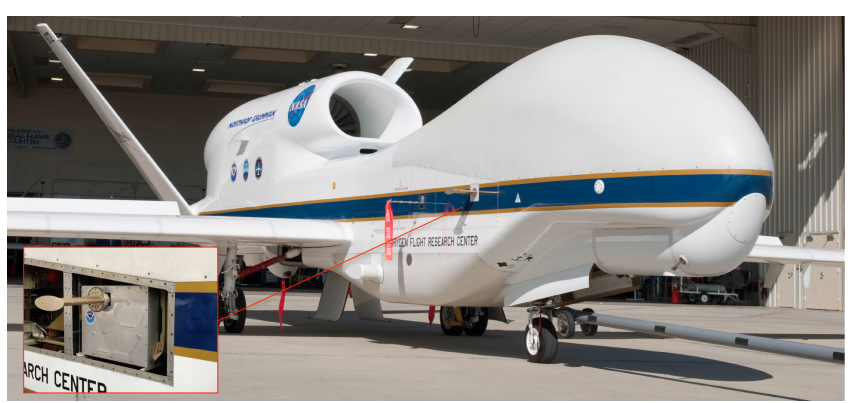

Figure 6. Photo of the NASA Global Hawk showing the location of the NOAA Water instrument inlet during the ATTREX mission (photo: T. Tschida, NASA; inset photo: T. Thornberry).

the thin plate at the end of the pylon, allows for sampling of ambient water vapor while rejecting cloud particles. The design is similar to that described in Popp et al. (2004) for sampling gas-phase nitric acid while excluding nitric acid trihydrate particles, and that described by Perring et al. (2013) for sampling submicron aerosol while rejecting cloud particles. A similar inlet was used with the NOAA CIMS $\mathrm{H}_{2} \mathrm{O}$ instrument (Thornberry et al., 2013) for water vapor measurements during the MACPEX campaign, where the measurements showed no detectable contamination from cloud water during extensive cirrus sampling. The WV sample line is constructed of $0.46 \mathrm{~cm}$ ID electropolished stainless steel tubing (WinTech 10, Winter Technologies, Pacific, MO, USA), which was found in our previous laboratory experiments to produce little hysteresis from rapid changes in water vapor at mixing ratios between 1 and $50 \mathrm{ppm}$ (Thornberry et al., 2013). A section of the WV inlet line closest to the tip is heated to $50^{\circ} \mathrm{C}$ to prevent condensation in the inlet.

\subsubsection{Total water inlet}

The sampling point for the TW channel is located at the end of a forward-facing $0.46 \mathrm{~cm}$ ID tube that affords sampling of both water vapor and condensed-phase water. The inlet tube is oriented parallel to the aircraft longitudinal axis at a distance of $22.5 \mathrm{~cm}$ from the fuselage surface and extends $6.7 \mathrm{~cm}$ forward from the leading edge of the pylon and tapering $\left(20^{\circ}\right)$ to a knife edge at the tip. Inside the pylon, $10.5 \mathrm{~cm}$ from the tip, the inlet tube makes a sharp (mitered) $90^{\circ}$ turn to facilitate impaction of large ice particles on the heated inlet wall. Nine centimeters of the forward facing sample line is enclosed in a $0.2 \mathrm{~cm}$ thick copper sheath extending from a copper block enclosing the bend that is maintained at $180^{\circ} \mathrm{C}$. After the bend, the sample line passes through the catalyst heater block, also controlled to $180^{\circ} \mathrm{C}$, before connecting to the heated $\left(30^{\circ} \mathrm{C}\right)$ interface flange at the fuselage surface and entering the instrument.

The controlled inlet flow of $600 \mathrm{sccm}$ causes the sampling to be subisokinetic, i.e., the sample air velocity inside the inlet $(U)$ is lower than the free-stream velocity $\left(U_{0}\right)$ at 
sampling altitudes and typical high-altitude research aircraft speeds $\left(140-200 \mathrm{~m} \mathrm{~s}^{-1}\right)$. This subisokinetic sampling leads to an inertially enhanced aspiration efficiency for particles into the inlet (Belyaev and Levin, 1974; Krämer and Afchine, 2004; Eddy et al., 2006; Davis et al., 2007a). As a result, cirrus particle number densities in the sample flow are enhanced by a factor, EF, defined as the ratio of particle number concentration entering the inlet tube to that in the free stream. The EF is a function of the inlet geometry, aircraft attitude, the ratio of the free-stream flow to the inlet flow $\left(U_{0} / U\right)$, and the Stokes numbers (Stk) of the particles. Since the mass flow through the TW inlet is constant, the volumetric flow rate and therefore the sample flow velocity, $U$, is a function of the ambient pressure and temperature and varies significantly with altitude. The parameterization developed by Eddy et al. (2006, Eq. 15) based on computational fluid dynamic simulations of various inlet geometries was used to calculate the particle-size-dependent EF for the TW inlet. Figure 7 shows calculated EF curves as a function of particle diameter for typical TTL operating conditions of the Global Hawk UAS. A density of $0.7 \mathrm{~g} \mathrm{~cm}^{-3}$ was used for the calculations based on the reported effective density of small $(<50 \mu \mathrm{m})$ cirrus particles by Cotton et al. (2013). EF curves calculated for a particle density of $0.9 \mathrm{~g} \mathrm{~cm}^{-3}$ (close to the bulk density of ice) are displayed as well to show the sensitivity of the calculated EF to the assumed density. The subplot in Fig. 7 shows that the potential error associated with using a given value in this range for the density is $<3 \%$ for particles greater than $5 \mu \mathrm{m}$, but becomes large (35-45\%) for particles near $1 \mu \mathrm{m}$. As expected, the value of the EF is near unity for small particles $(<0.2 \mu \mathrm{m})$ and increases with particle size. For particles larger than approximately $7 \mu \mathrm{m}$ in diameter, typical of cirrus particles, the EF for the TW inlet is within $2 \%$ of the maximum value of $U_{0} / U$, which is in the range of 30 to 50 for Global Hawk TTL flight conditions. This subisokinetic sampling enhancement results in a significantly increased sensitivity to cirrus IWC.

After cloud particles are sampled into the inlet, the condensed-phase water must be vaporized in order for it to be measured by the instrument. The high-temperature section of the TW inlet consists of $9 \mathrm{~cm}$ of the forward-facing tube plus an additional $19 \mathrm{~cm}$ length following the $90^{\circ}$ bend. Calculations of the sublimation of ice particles (assumed to be solid spheres with density $0.7 \mathrm{~g} \mathrm{~cm}^{-3}$ ) in the inlet at a pressure of $85 \mathrm{hPa}$ indicate that particles less than $7 \mu \mathrm{m}$ diameter will vaporize before reaching the bend, and particles less than $15 \mu \mathrm{m}$ diameter would completely vaporize within the $28 \mathrm{~cm}$ high-temperature region, even without contacting the heated walls. Particles larger than $15 \mu \mathrm{m}$ initial diameter have sufficient residual inertia that they will impact the tubing at the $90^{\circ}$ bend, potentially sticking and greatly increasing heat transfer or shattering into small fragments (Korolev et al., 2013a), accelerating subsequent vaporization. Calculations at $150 \mathrm{hPa}$ indicate that particles up to $21 \mu \mathrm{m}$ would sublimate in the sample flow within the high-temperature re-

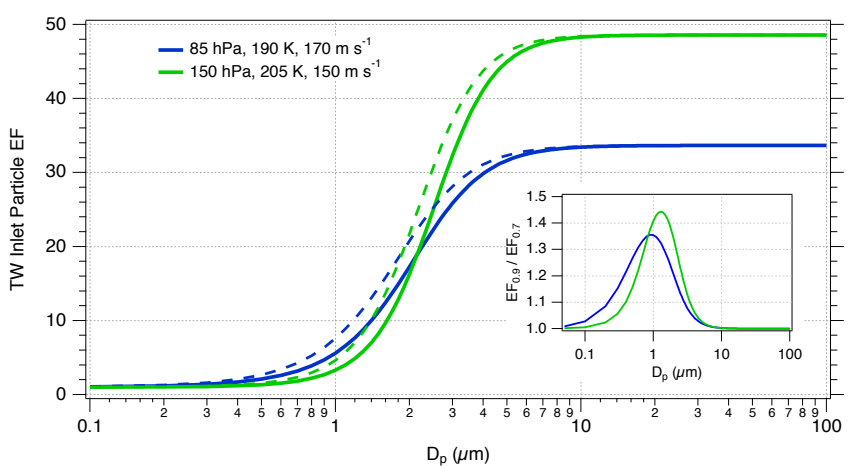

Figure 7. TW inlet particle aspiration enhancement factor (EF) as a function of particle diameter $\left(D_{\mathrm{p}}\right)$ calculated using the formulation of Eq. (15) in Eddy et al. (2006) for the TW inlet geometry and assumed ice particle densities of $0.7 \mathrm{~g} \mathrm{~cm}^{-3}$ (solid) and $0.9 \mathrm{~g} \mathrm{~cm}^{-3}$ (dashed). The curves represent conditions near the tropical tropopause (approximately $17.6 \mathrm{~km}$, blue) and near the bottom (approximately $14.4 \mathrm{~km}$, green) of the typical NASA Global Hawk operational altitude range during the ATTREX mission. The inset plot shows the ratio $\mathrm{EF}_{0.9} / \mathrm{EF}_{0.7}$ as a function of particle diameter to illustrate the effect of assumed particle density on the inlet EF.

gion, while particles with an initial diameter $>20 \mu \mathrm{m}$ will impact the tubing wall at the bend. With repetition of the calculations for an ice crystal density of $0.9 \mathrm{~g} \mathrm{~cm}^{-3}$, the diameters for both complete sublimation and impaction decrease slightly $(\sim 15 \%)$, but it remains the case that the diameter of particles large enough to not fully vaporize in the heated sample flow have sufficient remaining inertia at the $90^{\circ}$ bend to insure impaction on the hot tubing wall. Adequate models do not exist to provide a full description of ice particle shattering/sticking and collisional heat transfer from the walls in order to accurately calculate the details of vaporization of large ice crystals and their fragments. However, based on our calculations of sublimation within the high-temperature zone of the inlet, the rapid vaporization that will occur from contact with the hot tubing surfaces, and the additional $40 \mathrm{~cm}$ of warm $\left(20-40^{\circ} \mathrm{C}\right)$ inlet tubing through which the sample flow passes prior to reaching the absorption cell, we believe it is reasonable to assume that all condensed-phase water entering the TW inlet is vaporized prior to measurement.

The direct measurement of the water mixing ratio in the TW channel is defined as enhanced total water (eTW), which is composed of ambient water vapor $\left(\mathrm{H}_{2} \mathrm{O}_{\text {vap }}\right)$ and evaporated, inertially enhanced IWC (eIWC) as

$\mathrm{eTW}=\mathrm{H}_{2} \mathrm{O}_{\text {vap }}+\mathrm{EF} \cdot \mathrm{IWC}=\mathrm{H}_{2} \mathrm{O}_{\text {vap }}+$ eIWC.

The actual IWC of a sampled cirrus cloud is then determined as

$\mathrm{IWC}=\left(\mathrm{eTW}-\mathrm{H}_{2} \mathrm{O}_{\text {vap }}\right) / E F$,

where $\mathrm{H}_{2} \mathrm{O}_{\text {vap }}$ is measured in the WV channel, and the overall $\mathrm{EF}$ is determined by convolving the calculated EF curve 
for the immediate sampling conditions with an assumed cirrus ice particle size distribution or that provided by a comeasuring cloud probe instrument. Due to the EF size dependence for particles $<7 \mu \mathrm{m}$, uncertainty in the assumed or measured particle size distribution for cirrus with a significant mass fraction in small particles will lead to uncertainty in the determination of IWC.

\subsection{Calibration system}

The NOAA Water instrument uses an onboard calibration system to evaluate the stability of the sensitivity and background of the WV channel during flight. The calibration system is similar to the one used previously in the NOAA CIMS $\mathrm{H}_{2} \mathrm{O}$ instrument (Thornberry et al., 2013) and is based on the catalytic oxidation of $\mathrm{H}_{2}$ standards to produce known $\mathrm{H}_{2} \mathrm{O}$ mixing ratios (Rollins et al., 2011). The current system (see Fig. 2) consists of one dry synthetic air (zero air, ZA) cylinder (M22A, Luxfer Gas Cylinders, Riverside, CA, USA) and two cylinders (M09B, Luxfer) containing different mixing ratios of $\mathrm{H}_{2}$ in air. The ZA is passed through a $1 \mathrm{~cm}$ ID by $25 \mathrm{~cm}$ long stainless steel tube containing a molecular sieve desiccant (BMSR-1, Agilent Technologies Inc., Santa Clara, CA, USA), which reduces the residual water vapor mixing ratio in the ZA. This moisture trap is located downstream of the ZA pressure regulator (Series 4300-N, Premier Industries, Blaine, MN, USA) to capture water from as many potential leaks as possible before the ZA is directed to the inlets. The catalyst assembly, located in the inlet pylon, consists of a $14 \mathrm{~cm}$ long, $0.21 \mathrm{~cm}$ ID, electropolished stainless steel tube containing two $2.5 \mathrm{~cm} \times 5 \mathrm{~cm}$ pieces of tightly rolled Pt mesh (part no. 298093-1.7G, Sigma-Aldrich Co., St. Louis, MO, USA). The catalyst is maintained at a temperature of $180^{\circ} \mathrm{C}$ and a pressure above $2000 \mathrm{hPa}$, which was demonstrated to yield complete conversion of $\mathrm{H}_{2}$ to $\mathrm{H}_{2} \mathrm{O}$ for a similar geometry and flow rates to those used in the NOAA Water instrument (Rollins et al., 2011).

Mass flow controllers (MC-Series, Alicat Scientific Inc., Tucson, AZ, USA), which were tested and found to be insensitive to changes in ambient enclosure pressure, are used to control the ZA flows to the inlets and the $\mathrm{ZA}$ and $\mathrm{H}_{2}$ /air flows through the Pt catalyst.

To perform a calibration, the ZA flow to the $\mathrm{WV}$ inlet is set to $1000 \mathrm{sccm}$, overflowing the inlet with $\mathrm{ZA}$. The $\mathrm{H}_{2}$ /air flows through the catalyst are adjusted in a series of steps between 2 and $20 \mathrm{sccm}$ and the output of the catalyst is added to the ZA in the sample flow to produce a series of known $\mathrm{H}_{2} \mathrm{O}$ mixing ratios, which are used periodically to determine the sensitivity of the WV channel. Due to space and weight constraints and the desire to use a minimum number of fittings (potential leaks), only the WV channel is calibrated in flight. The stability of the sensitivity of the TW channel during flight is assessed by comparing its signal with that of the WV channel when sampling in cloud-free air. The calibrations performed during flight are compared with identical calibration sequences run on the ground to verify the consistency of the calibration system during flight.

To mitigate the potential effects of parasitic water from infinitesimal leaks into the calibration system, $10 \mathrm{sccm}$ flows of ZA are used to continuously flush the ZA and calibration system tubing out to the inlet addition points and back through return flow controllers (see Figs. 2 and 5). The return flow controllers are set to additionally pull small (10$15 \mathrm{sccm}$ ) flows of sample air from the inlets to prevent ZA from reaching the sample flow during ambient sampling.

\subsection{Data system}

Instrument control, data acquisition, and communication with the aircraft are accomplished using a custom LabView program running on a CompactRIO system (National Instruments Inc., Austin, TX, USA). Custom Arduino-based electronics boards are used for temperature control of instrument components and operation of the flow- and pressure-control butterfly valves.

Instrument temperatures, pressures, and flows (housekeeping) along with laser parameters, N2f signals, and calculated $\mathrm{H}_{2} \mathrm{O}_{\text {vap }}$ and eTW mixing ratios are recorded at $1 \mathrm{~Hz}$ $\left(\sim 4 \mathrm{MB} \mathrm{h}^{-1}\right)$ for post-flight data processing and instrument performance evaluation. A subset of this data can be transmitted to the ground for real-time reporting of mixing ratios and monitoring of instrument performance during flight if communication is available. The 1024-point DC and $2 \mathrm{f} \mathrm{spec-}$ tra for each channel are acquired at $10 \mathrm{~Hz}$, coaveraged, and saved at $1 \mathrm{~Hz}\left(29.5 \mathrm{MB} \mathrm{h}^{-1}\right)$. The instrument can operate entirely autonomously or with user interaction, depending on the communications capability of the aircraft platform.

\section{Instrument performance}

The first field deployment of the NOAA Water instrument occurred in the second phase of the ATTREX mission in January-March 2013, during which the instrument was integrated on the NASA Global Hawk UAS. During this mission, the Global Hawk conducted six research flights flight with durations of $24( \pm 0.3)$ hours, allowing for transit south from NASA Dryden Flight Research Center in California to the central and eastern tropical Pacific with substantial time at low latitudes to conduct extensive sampling in the TTL. Measured water vapor mixing ratios in the TTL reached values as low as $1.5 \mathrm{ppm}$ and cirrus clouds with a wide range of IWC were encountered.

Operational procedures for the NOAA Water instrument during ATTREX involved calibrating the instrument on the ground between flights, as well as extensively in the laboratory before and after the mission. These calibrations were conducted with sample flows containing $\mathrm{H}_{2} \mathrm{O}$ mixing ratios in the range between 0.5 and $2500 \mathrm{ppm}$ as quantified by the MBW frost point hygrometer. The calibration flows 


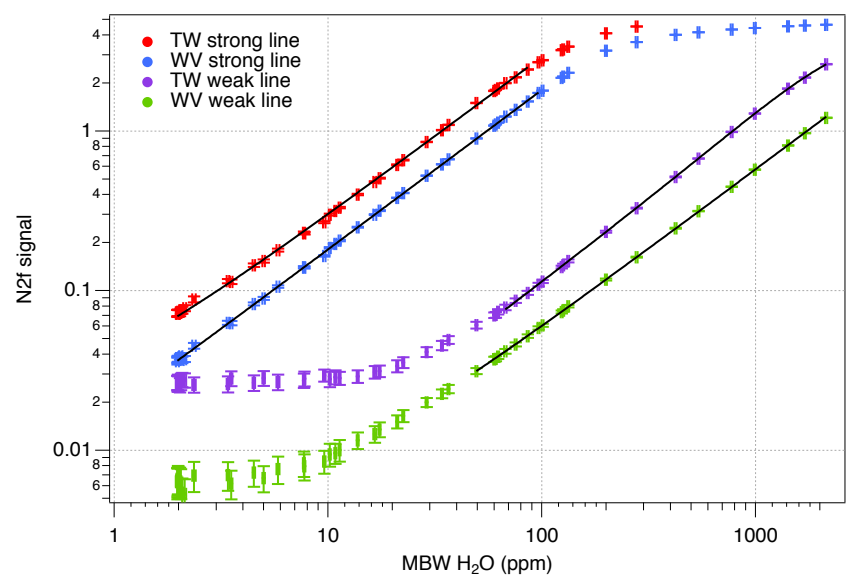

Figure 8. Laboratory calibration curves showing the laser power normalized second harmonic (N2f) signals from the strong and weak absorption lines (2693.82 and $2694.06 \mathrm{~nm}$, respectively) in the WV and TW channels as a function of the $\mathrm{H}_{2} \mathrm{O}$ mixing ratio in the sample flow measured by the MBW reference hygrometer. Each data point represents an average of 100-300 s of data at a constant mixing ratio. The error bars are the standard deviation of the $\mathrm{N} 2 \mathrm{f}$ signal in each interval. The black lines are the weighted orthogonal linear regression fits to the data, which are used to determine instrument sensitivity for each absorption line. The differences in $\mathrm{N} 2 \mathrm{f}$ values between channels at the same MBW value are due to intrinsic performance and configuration differences between the channels.

were generated by an external $\mathrm{H}_{2} / \mathrm{Pt}$ catalytic $\mathrm{H}_{2} \mathrm{O}$ source (Rollins et al., 2011) and distributed to the instrument and the MBW through a common manifold. Figure 8 presents results from one laboratory calibration over the range 2 $2140 \mathrm{ppm}$ showing the calibration ranges for both weak and strong lines of both channels. The nonlinearity in the N2f signal that arises from high optical depth is apparent at mixing ratios above $100 \mathrm{ppm}$ in the strong absorption lines, while electronic noise and optical fringing produce nonlinearity in the WV and TW weak absorption line signals below 40 and $60 \mathrm{ppm}$, respectively. Repeated calibrations performed with many hours of continuous operation at mixing ratios less than $20 \mathrm{ppm}$ were used to assess the linearity of the strong absorption line N2f signals at these low mixing ratios and to quantify the background water signal in each channel (Fig. 9). Fringes in the TW channel were somewhat larger than those in the WV channel and led to larger variations over time in the TW N2f signal at low mixing ratios. The background equivalent water value in the WV channel due to residual trapped water in the laser and detector packages was determined to be $0.3 \pm 0.1 \mathrm{ppm}$, while that in the TW channel was $0.3 \pm 0.2 \mathrm{ppm}$.

During the ATTREX flights, $\mathrm{H}_{2} \mathrm{O}$ vapor and eTW mixing ratios were calculated in real time on a $1 \mathrm{~Hz}$ basis from the N2f signals in the WV and TW channels and transmitted to the ground when communication was available. Because data reduction is performed by empirically calibrating
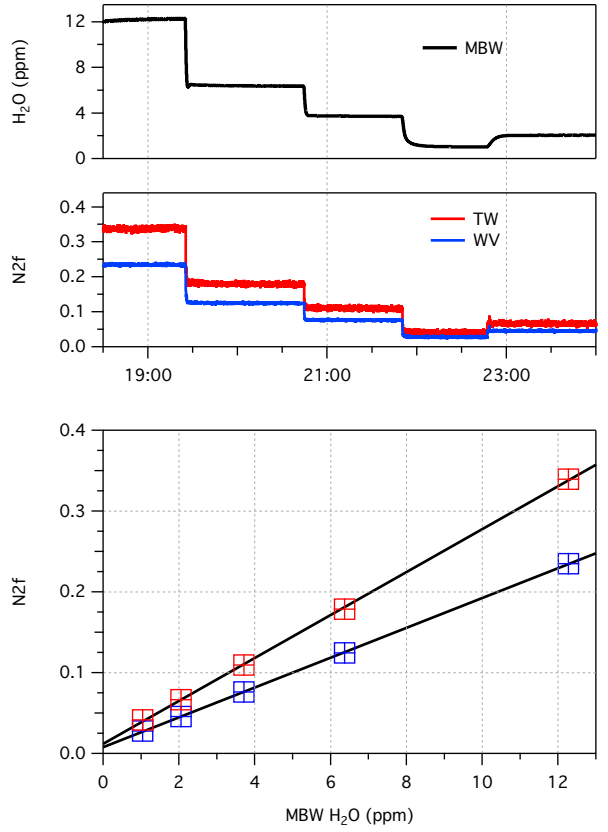

Figure 9. Laboratory calibration of the WV and TW channel strong absorption line signals at low $\mathrm{H}_{2} \mathrm{O}$ mixing ratios. Top: time series of water vapor values in the sample flow as measured by the MBW reference hygrometer. Middle: corresponding time series of the strong absorption line laser power normalized second harmonic (N2f) signals in each channel. Bottom: linearity of the N2f signals at low mixing ratios. Repeated long-duration calibrations at low mixing ratios were used to quantify and verify the stability of the background water signal from residual water in the laser and detector packages.

the $\mathrm{N} 2 \mathrm{f}$ signal against a $\mathrm{H}_{2} \mathrm{O}$ reference standard (MBW), the measurement accuracy does not depend on highly accurate knowledge of the laser modulation amplitude. Further, uncertainties due to changes in spectral line shape and line strength with changes in gas temperature and pressure do not contribute to measurement uncertainty as long as these parameters do not change between ground-based calibrations and in-flight measurements. Mixing ratios were calculated from the N2f signals in the low optical depth regime for each line, where the nonlinearity in the instrument response is less than $0.5 \%$. Only the TW channel measured values high enough to require use of the weak absorption line, which was used for mixing ratios above $80 \mathrm{ppm}$.

During flights, the detection cell pressures were maintained to within $\pm 0.7 \%$ of the pressure at which the channel was calibrated in the laboratory, and the absorption cell temperatures were maintained within a $\pm 0.03^{\circ} \mathrm{C}$ range after the optical cell sub-enclosure reached its temperature set point. Therefore variations in the instrument sensitivity due to changes in these parameters are negligible. To directly verify the stability of the instrument response during flight operation, the ambient flow in the WV channel was periodically replaced with calibration flows produced using the $\mathrm{Pt} / \mathrm{H}_{2} / \mathrm{ZA}$ 


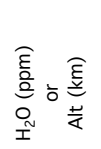

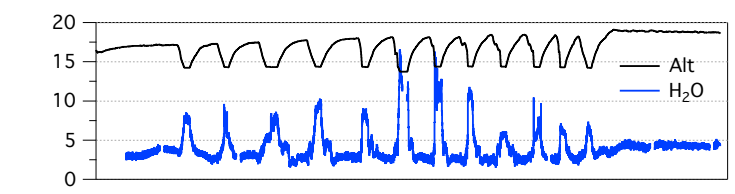

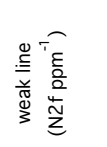

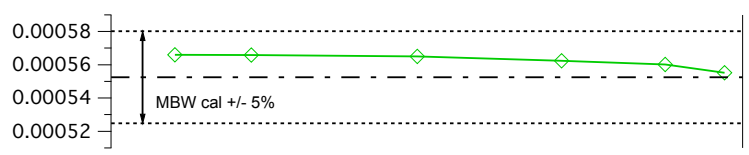

0.019

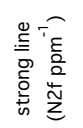

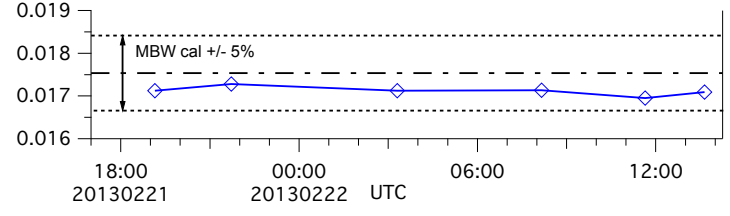

Figure 10. WV channel sensitivity measured during in-flight calibrations from a flight on 21-22 February 2013. Top panel: water vapor mixing ratios and aircraft altitude during a series of profiles through the TTL. Middle panel: calibration slopes (sensitivity) for the weaker absorption line $\left(3711.9 \mathrm{~cm}^{-1}\right)$. Bottom panel: calibration slopes for the strong $\mathrm{H}_{2} \mathrm{O}$ absorption line $\left(3712.2 \mathrm{~cm}^{-1}\right)$. Each data point represents a calibration procedure in which dry synthetic air displaced the ambient flow for $8.7 \mathrm{~min}$ and a series of $8 \mathrm{H}_{2} \mathrm{O}$ mixing ratios between 2 and $400 \mathrm{ppm}$ were added in time intervals of 40-60 s. In the middle and bottom panels, the dash-dot horizontal lines indicate the sensitivity measured in the laboratory prior to the flight. The dotted lines indicate the $\pm 5 \%$ range surrounding the pre-flight laboratory value. The solid lines simply connect the data points as an aid to the reader.

system. Figure 10 shows results from the in-flight calibrations during the flight on 21-22 February 2013. The measured instrument response (sensitivity) for both $\mathrm{H}_{2} \mathrm{O}$ spectral lines in individual calibrations during the flight agreed with those measured in the laboratory to better than $4 \%$, which is within the uncertainty expected of the onboard calibration system. These results are typical of the in-flight calibrations on all of the ATTREX flights.

In-flight measurement precision was evaluated by calculating the distribution of $1 \mathrm{~s}$ changes in the WV channel measurements $(\Delta \mathrm{WV}=\mathrm{WV}[t]-\mathrm{WV}[t-1])$. Figure 11 shows a histogram of $\Delta W V$ from the 21-22 February 2013 flight with a Gaussian fit indicating that the noise is normally distributed with a width of $0.34 \mathrm{ppm}$, corresponding to a $1 \sigma$ precision of $0.17 \mathrm{ppm}$. Noise in the TW channel was typically slightly higher than in the WV channel ( 0.25 for the 21-22 February flight). The observed in-flight precision is independent of signal amplitude and compares well, given a contribution to the $1 \mathrm{~s}$ changes from real atmospheric variability, with the typical value of $0.1 \mathrm{ppm}$ observed while sampling stable mixing ratios in the laboratory.

Also shown in Fig. 11 is the histogram of the difference between $1 \mathrm{~s}$ TW and WV channel signals during cloud-free sampling. This difference was normally distributed and centered near zero $(-0.012 \mathrm{ppm})$. The detection limit for eIWC is defined as twice the standard deviation $(2 \sigma)$ in the clear-
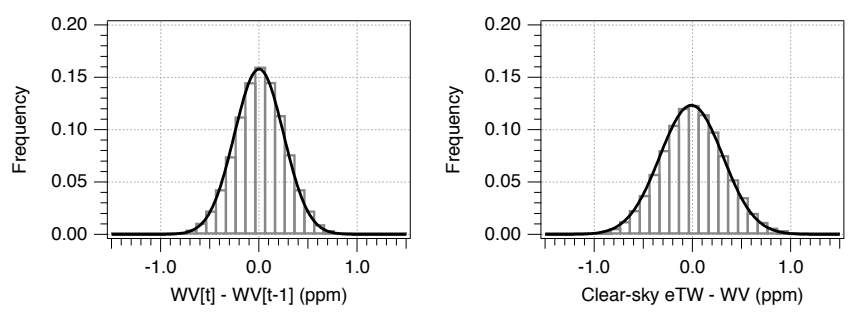

Figure 11. Left: histogram of $1 \mathrm{~s}$ changes in the WV channel (strong line) during the 21-22 February 2013 flight. The width of the Gaussian fit to the distribution is 0.34 , indicating the signal noise is normally distributed with $\sigma=0.17 \mathrm{ppm}$. Right: histogram of the difference between $1 \mathrm{~s}$ measurements in the TW and WV channels during cloud-free sampling periods of the 21-22 February 2013 flight. The difference is normally distributed around 0 with a width of $0.45 \mathrm{ppm}$. This scatter yields a detection threshold $(2 \sigma)$ for inertially enhanced ice water content, eIWC, of $0.641 \mathrm{ppm}$.

sky difference of the signal. For the 21-22 February flight this results in an eIWC detection limit of $0.641 \mathrm{ppm}$. Assuming the cirrus particles are greater than $8 \mu \mathrm{m}$ effective diameter, the calculated EFs of 33-48 yield an IWC mixing ratio detection limit from 0.023 to $0.013 \mathrm{ppm}$, depending on altitude. Converting these numbers to mass, the IWC detection limit was approximately $2 \mu \mathrm{g} \mathrm{m}^{-3}$ across the sampling altitude range. Figure 12 shows a sample time series of WV and eTW mixing ratios during a vertical profile through the TTL from the 21-22 February flight. Cirrus encounters are clearly visible on both the ascent and descent. This data sample illustrates the typical instrumental precision in the measurements, as well as the good agreement between the WV and TW channels.

\subsection{Water vapor measurement uncertainty}

The principal sources of uncertainty in the determination of ambient $\mathrm{H}_{2} \mathrm{O}$ mixing ratios in the NOAA Water instrument are (1) the accuracy of the MBW reference frost point hygrometer, (2) uniformity of the $\mathrm{H}_{2} \mathrm{O}$ mixing ratio in the external calibration flows to the MBW and the NOAA Water instrument (analytical split), (3) stability of the absorption cell pressures, (4) temperature of the sample gas in the absorption cells, (5) linearity of the calibration fit, and (6) variation of optical fringes in the wavelength scan.

The NIST-traceable accuracy of the MBW frost point determination is $0.1^{\circ} \mathrm{C}$, which at $850 \mathrm{hPa}$ (typical ambient pressure in Boulder, $\mathrm{CO}$ ) corresponds to an uncertainty of $1.6 \%$ at $1 \mathrm{ppm}$ decreasing to approximately $1 \%$ at $1000 \mathrm{ppm}$. Potential issues with analytical split of the external calibration between the MBW and the instrument were addressed by examining the repeatability of the laboratory calibrations with a number of different plumbing configurations and found to be negligible. The uncertainty arising from changes to the sensitivity $\left(\mathrm{H}_{2} \mathrm{O}\right.$ absorption) with changes in cell pressure are similar in magnitude to the variations in the cell pressure for 


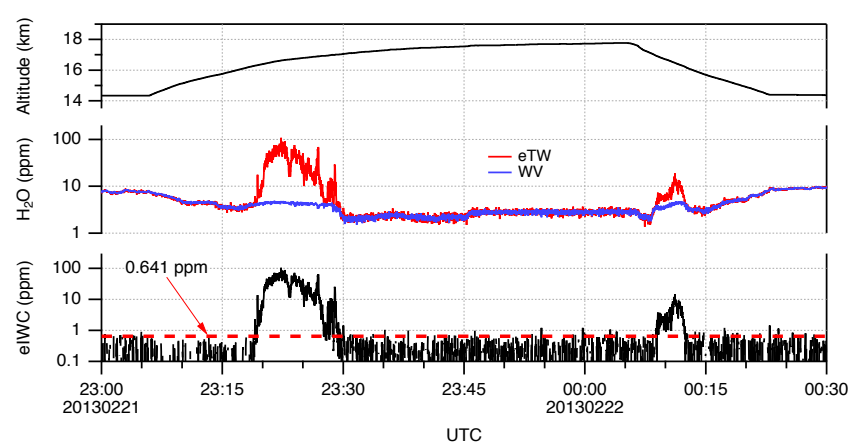

Figure 12. Time series of measured $\mathrm{H}_{2} \mathrm{O}$ vapor (WV) and enhanced total water (eTW) including two cloud encounters during a vertical profile maneuver through the TTL during the flight of 21-22 February 2013. The top section shows the aircraft altitude. The middle section shows the measured $\mathrm{H}_{2} \mathrm{O}_{\text {vap }}$ (blue) and eTW (red) mixing ratios. The bottom section shows the calculated enhanced ice water content, eIWC (=eTW $\left.-\mathrm{H}_{2} \mathrm{O}_{\text {vap }}\right)$. The dashed red line indicates the detection threshold for eIWC of $0.641 \mathrm{ppm}$ determined from the precision $(2 \sigma)$ in the difference between the two channels during cloud-free sampling.

small changes, and were typically less than $0.7 \%$. The temperature of the sample gas in the absorption cells was not directly measured, but the active heating of the inlets and interface flange, the small range of temperature in the main instrument enclosure during flight $\left(10-20^{\circ} \mathrm{C}\right)$, and thermal equilibration with the $20 \mathrm{~cm}$ of inlet tubing within the temperaturecontrolled sub-enclosure result in small $\left(<1^{\circ} \mathrm{C}\right)$ calculated variations in the temperature of the sample gas entering the absorption cells. Based on HITRAN calculations, a $1{ }^{\circ} \mathrm{C}$ change in gas temperature would result in less than a $0.4 \%$ change in the absorption line strength. The insensitivity of the measurement to changes in external temperature is supported by the lack of any observed difference in the signals in the laboratory at constant $\mathrm{H}_{2} \mathrm{O}$ mixing ratio with and without the inlet and interface flange heaters operating. The uncertainty due to changes to the $\mathrm{N} 2 \mathrm{f}$ signal caused by variations in the optical fringes in the spectrum that arise from small changes in the optical path with fluctuations in cell temperature was assessed by analyzing extended (up to $12 \mathrm{~h}$ ) sampling of constant mixing ratios. The observed variations in the signal due to shifting optical fringes were equivalent to less than $0.1 \mathrm{ppm} \mathrm{H}_{2} \mathrm{O}$ for temperature fluctuations similar to those observed in flight $\left( \pm 0.03^{\circ} \mathrm{C}\right)$. During the 2013 ATTREX deployment, including pre- and post-mission calibrations and calibrations conducted between flights, the goodness of the individual linear fits to the calibration data was better than $4 \%$, and the average difference between individual calibrations of the WV channel was described by the linear function $0.1+0.005 \cdot \mathrm{H}_{2} \mathrm{O}$. Combining the uncertainty arising from these factors yields an accuracy of $5 \% \pm 0.15 \mathrm{ppm}$ for the $\mathrm{WV}$ channel. Including the typical precision value of $0.17 \mathrm{ppm}$, the overall uncertainty in the

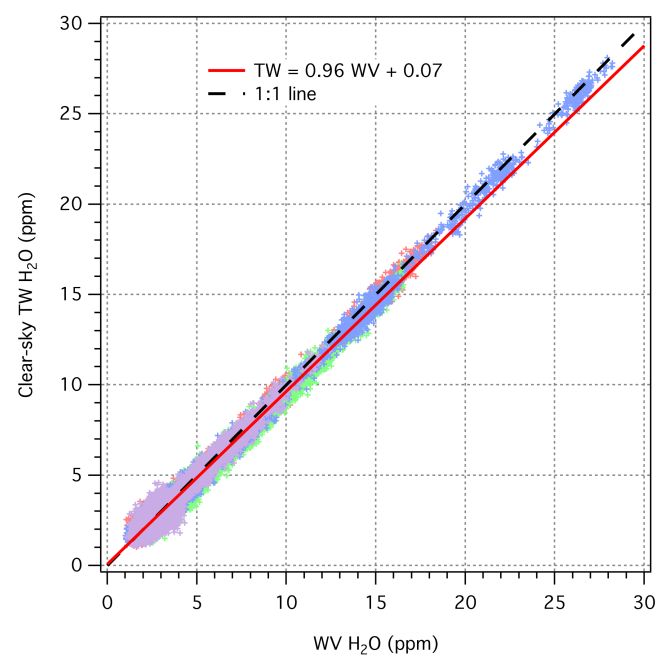

Figure 13. Correlation of $\mathrm{H}_{2} \mathrm{O}$ measured in the TW channel with that measured in the WV channel for cloud-free sampling conditions during ATTREX 2013 flights. The slope of the correlation calculated using linear orthogonal distance regression was 0.96 . Individual flight correlation slopes ranged from 0.95 to 0.98 and the $r^{2}$ values of the correlations ranged from 0.92 to 0.99 .

$\mathrm{H}_{2} \mathrm{O}$ mixing ratio in the WV cell is $5 \% \pm 0.23 \mathrm{ppm}$ for a $1 \mathrm{~s}$ measurement. For the eTW $\mathrm{H}_{2} \mathrm{O}$ measurement in the TW channel, the overall uncertainty was slightly higher at $6 \% \pm$ $0.35 \mathrm{ppm}$ due to contributions from larger optical fringes in the spectrum and slightly higher electronic noise (precision). The overall good agreement between TW and WV channels during periods of cloud-free sampling in all of the ATTREX 2013 flights is shown in the correlation plot in Fig. 13. An orthogonal linear regression fit to all of the data yielded a slope of 0.96 and the correlation had an $r^{2}$ value of 0.97 . Regressions for individual flights ranged from 0.95 to 0.98 , indicating there was some variation in relative sensitivity over time. This variation appears to arise primarily from optical fringes in the TW channel that affected the signal at lower mixing ratios. No consistent offset between the two channels in flight was observed.

\subsection{Ice water content measurement uncertainty}

A number of additional sources of uncertainty affect the IWC measurement. These include (1) the particle aspiration efficiency of the inlet, (2) size distribution of the ice particles, (3) completeness of ice particle vaporization within the inlet, (4) inlet geometric sampling area, and (5) disturbance of the ambient cirrus ice particle distribution at the sampling point by the presence of the aircraft. Conservative calculations of ice particle vaporization indicate that an assumption of complete vaporization of all ice particles within the TW inlet prior to measurement is reasonable and incomplete vaporization therefore contributes negligibly to the overall IWC measurement uncertainty. Calculating the TW inlet EF 
requires knowledge of a number of atmospheric (pressure, temperature) and aircraft (true air speed, pitch) and instrument (inlet flow) parameters that all contribute some uncertainty. For ATTREX, the atmospheric and aircraft parameters were measured by the Meteorological Measurement System (NASA Ames Research Center, T. V. Bui, PI), which reports uncertainties of $\pm 0.3 \mathrm{hPa}, \pm 0.3 \mathrm{~K}$ and $\pm 1.0 \mathrm{~m} \mathrm{~s}^{-1}$ for temperature, pressure, and true air speed, respectively. These uncertainties are sufficiently small to contribute only about $1 \%$ uncertainty to the calculated value of the free-stream flow, $U_{0}$. The uncertainty in inlet flow measured by the TW sample mass flow meter is $3 \%$. Eddy et al. (2006) report that the EF parameterization presented (Eq. 15) agreed with their detailed computational fluid dynamics simulations to within $20 \%$ for most Stk values, so the uncertainty in EF contributes significantly to the overall uncertainty. The uncertainty in IWC determination arising from the size dependence of the EF depends on the fraction of ice mass in crystals with diameters less than $7 \mu \mathrm{m}$, where the EF begins to decrease significantly from the asymptotic value of $U / U_{0}$. If all ice mass were in particles of $5 \mu \mathrm{m}$ diameter, assuming the $U_{0} / U$ value for the EF would result in an underestimate of IWC by less than $10 \%$, while if the particles were all $3 \mu \mathrm{m}$, the underestimate would rise to $33 \%$. Applying the calculated EF size dependence to a co-measured ice particle size distribution, if one is available, can reduce the magnitude of this uncertainty. The typical angle of attack of the Global Hawk while flying in the TTL was $<4^{\circ}$, so the uncertainty associated with the reduction in geometric inlet sampling area due to the flow angle is negligible. The effects of cloud ice particle shattering on probe and aircraft surfaces have been a significant issue in measurements of cirrus size distribution and habit (e.g., Korolev et al., 2013b). Shattering on the knife edge of the TW inlet does not present a major uncertainty for the IWC determination since it results in $<3 \%$ uncertainty in the inlet geometric area, and shattered particles entering the inlet are vaporized prior to measurement. Combining these uncertainty factors results in an overall uncertainty for IWC determination of $15-30 \%$, depending on the mass-weighted cloud particle size distribution.

Estimating the additional IWC uncertainty associated with potential sampling artifacts caused by the presence of the aircraft is difficult. During the ATTREX mission, the NOAA Water instrument was mounted in a forward fuselage bay on the right side of the aircraft, approximately $3 \mathrm{~m}$ behind the nose (see Fig. 6). Potential ice crystal bounce and deflection effects on sampling have not been investigated for the Global Hawk using computational fluid dynamic simulations, although in the future they could potentially yield some insight into these issues. In the comparison of total water measurements during the MidCiX campaign reported by Davis et al. (2007b), the reasonable agreement between three instruments sampling from different locations on the NASA WB-57F aircraft suggest that the effects for IWC measurement of the type reported here may be small.

\section{Summary}

The NOAA Water instrument was developed for accurate in situ measurements of water vapor and cirrus IWC in the TTL and elsewhere in the UT/LS, which are important for our understanding of the dynamical and microphysical processes that regulate the $\mathrm{H}_{2} \mathrm{O}$ distributions in this climatically important region. The instrument is based on TDL absorption spectroscopy of $\mathrm{H}_{2} \mathrm{O}$ in two single-reflection absorption cells with an absorption path length of $78.6 \mathrm{~cm}$. Wavelength modulation spectroscopy with a strong $\mathrm{H}_{2} \mathrm{O}$ absorption line near $2694 \mathrm{~nm}$ is used to achieve high sensitivity and good measurement precision at low-ppm $\mathrm{H}_{2} \mathrm{O}$ mixing ratios. A second, weaker absorption line is used to provide dynamic range for measurement of mixing ratios up to $2500 \mathrm{ppm}$. Data reduction is simplified by operating the absorption cells at constant pressure, temperature, and flow, independent of changes in the ambient sampling environment. The instrument is calibrated against a reference hygrometer on the ground and utilizes an onboard calibration system to verify the stability of the measurement sensitivity during flight. The in-flight calibrations are compared with identical calibration sequences run on the ground to verify the consistency of the calibration system during flight.

The dual-cell design of the instrument allows for simultaneous measurement of water vapor and enhanced total water for the determination of cirrus IWC. Air for the measurement of $\mathrm{H}_{2} \mathrm{O}$ vapor is sampled through an inlet oriented perpendicular to the free-stream flow past the aircraft in order to reject ice crystals, while a forward-facing, subisokinetic inlet produces inertially enhanced sampling of cirrus particles to yield high sensitivity to IWC.

The instrument was successfully deployed in multiple flights in the tropical UT/LS onboard the NASA Global Hawk UAS during the second deployment of the ATTREX mission in 2013. Based on flight performance, the overall uncertainty in the measurement of water vapor $(1 \mathrm{~s}, 1 \sigma)$ is $5 \% \pm 0.23 \mathrm{ppm}$, while uncertainty in the determination of cirrus IWC is estimated to be approximately $20 \%$ (15-30\%). The enhancement factor for ice particles larger than $7 \mu \mathrm{m}$ was calculated to be in the range of 33-48 depending on aircraft altitude, which results in an IWC detection limit of approximately $2 \mu \mathrm{g} \mathrm{m}^{-3}$. Measurements of $\mathrm{H}_{2} \mathrm{O}$ mixing ratio and cirrus IWC in the Pacific TTL during the ATTREX mission will be used to investigate the dynamic processes and microphysics related to the dehydration of air as it is transported through this region.

Acknowledgements. The authors thank Randy May of Port City Instruments for contributing his experience and expertise to the development of the NOAA Water instrument, and the ground and flight crews of the NASA Global Hawk UAS for their support during the ATTREX mission. This work was supported with funding from the NASA Upper Atmosphere Research Program, the NASA Radiation Sciences Program, the NASA Airborne Tropical 
TRopopause EXperiment, and the NOAA Climate Program Office.

Edited by: T. F. Hanisco

\section{References}

Belyaev, S. P. and Levin, L. M.: Techniques for collection of representative aerosol samples, J. Aerosol Sci., 5, 325-338, doi:10.1016/0021-8502(74)90130-X, 1974.

Brewer, A. W., Cwilong, B., and Dobson, G. M. B.: Measurement of absolute humidity in very dry air, Proc. Phys. Soc. London, 60, 52-70, doi:10.1088/0959-5309/60/1/307, 1948.

Brown, P. R. A. and Francis, P. N.: Improved Measurement of the Ice Water Content in Cirrus Using a Total-Water Probe, J. Atmos. Ocean. Technol., 12, 410-414, 1995.

Buchholz, B., Kühnreich, B., Smit, H. G. J., and Ebert, V.: Validation of an extractive, airborne, compact TDL spectrometer for atmospheric humidity sensing by blind intercomparison, App. Phys. B, 110, 249-262, doi:10.1007/s00340-012-5143-1, 2013.

Cotton, R. J., Field, P. R., Ulanowski, Z., Kaye, P. H., Hirst, E., Greenaway, R. S., Crawford, I., Crosier, J., and Dorsey, J.: The effective density of small ice particles obtained from in situ aircraft observations of mid-latitude cirrus, Q. J. R. Meteorol. Soc., 139, 1923-1934, doi:10.1002/qj.2058, 2013.

Davis, S. M., Hallar, A. G., Avallone, L. M., and Engblom, W.: Measurement of Total Water with a Tunable Diode Laser Hygrometer: Inlet Analysis, Calibration Procedure, and Ice Water Content Determination, J. Atmos. Ocean. Technol., 24, 463-475, doi:10.1175/JTECH1975.1, 2007a.

Davis, S. M., Avallone, L. M., Weinstock, E. M., Twohy, C. H., Smith, J. B., and Kok, G. L.: Comparisons of in situ measurements of cirrus cloud ice water content, J. Geophys. Res., 112, D10212, doi:10.1029/2006JD008214, 2007b.

Dessler, A. E.: A determination of the cloud feedback from climate variations over the past decade, Science, 330, 1523-1527, doi:10.1126/science.1192546, 2010.

Diskin, G. S., Podolske, J. R., Sachse, G. W., and Slate, T. A.: Open-path airborne tunable diode laser hygrometer, Proc. SPIE 4817, Diode Lasers and Applications in Atmospheric Sensing, 196 (September 24, 2002), doi:10.1117/12.453736, 2002.

Dorsi, S. W., Kalnajs, L. E., Toohey, D. W., and Avallone, L. M.: A fiber-coupled laser hygrometer for airborne total water measurement, Atmos. Meas. Tech., 7, 215-223, doi:10.5194/amt-7-2152014, 2014.

Eddy, P., Natarajan, A., and Dhaniyala, S.: Subisokinetic sampling characteristics of high speed aircraft inlets: A new CFDbased correlation considering inlet geometries, J. Aerosol Sci., 37, 1853-1870, doi:10.1016/j.jaerosci.2006.08.005, 2006.

Fahey, D. W., Gao, R.-S., Möhler, O., Saathoff, H., Schiller, C., Ebert, V., Krämer, M., Peter, T., Amarouche, N., Avallone, L. M., Bauer, R., Bozóki, Z., Christensen, L. E., Davis, S. M., Durry, G., Dyroff, C., Herman, R. L., Hunsmann, S., Khaykin, S. M., Mackrodt, P., Meyer, J., Smith, J. B., Spelten, N., Troy, R. F., Vömel, H., Wagner, S., and Wienhold, F. G.: The AquaVIT-1 intercomparison of atmospheric water vapor measurement techniques, Atmos. Meas. Tech., 7, 3177-3213, doi:10.5194/amt-7-3177-2014, 2014.
Forster, P. M. de F. and Shine, K. P.: Assessing the climate impact of trends in stratospheric water vapor, Geophys. Res. Lett., 29, 10-1-10-4, doi:10.1029/2001GL013909, 2002.

Fueglistaler, S., Dessler, A. E., Dunkerton, T. J., Folkins, I., Fu, Q., and Mote, P. W.: Tropical Tropopause Layer, Rev. Geophys., 47, RG1004, doi:10.1029/2008RG000267, 2009.

Fueglistaler, S., Liu, Y. S., Flannaghan, T. J., Haynes, P. H., Dee, D. P., Read, W. J., Remsberg, E. E., Thomason, L. W., Hurst, D. F., Lanzante, J. R., and Bernath, P. F.: The relation between atmospheric humidity and temperature trends for stratospheric water, J. Geophys. Res., 118, 1052-1074, doi:10.1002/jgrd.50157, 2013.

Jensen, E. J., Smith, J. B., Pfister, L., Pittman, J. V., Weinstock, E. M., Sayres, D. S., Herman, R. L., Troy, R. F., Rosenlof, K., Thompson, T. L., Fridlind, A. M., Hudson, P. K., Cziczo, D. J., Heymsfield, A. J., Schmitt, C., and Wilson, J. C.: Ice supersaturations exceeding $100 \%$ at the cold tropical tropopause: implications for cirrus formation and dehydration, Atmos. Chem. Phys., 5, 851-862, doi:10.5194/acp-5-851-2005, 2005.

Kaufman, S., Voigt, C., Jeßberger, P., Jurkat, T., Schlager, H., Schwarzenboeck, A., Klingbiel, M., and Thornberry, T.: In situ measurements of ice saturation in young contrails, Geophys. Res Lett., 41, 702-709, doi:10.1002/2013GL058276, 2014.

Kirk-Davidoff, D. B., Hintsa, E. J., Anderson, J. G., and Keith, D. W.: The effect of climate change on ozone depletion through changes in stratospheric water vapour, Nature, 402, 399-401, doi:10.1038/46521, 1999.

Kley, D. and Stone, E. J.: Measurement of water vapor in the stratosphere by photodissociation with Ly $\alpha(1216 \AA)$ light, Rev. Sci. Inst., 49, 691-697, doi:10.1063/1.1135596, 1978.

Kley, D., Russell III, J. M., and Phillips, C. (Eds.): SPARC Assessment of Upper Tropospheric and Stratospheric Water Vapour, World Clim. Res. Prog., Geneva, Switzerland, 2000.

Kluczynski, P. and Axner, O.: Theoretical description based on Fourier analysis of wavelength-modulation spectrometry in terms of analytical and background signals, App. Optics, 38, 5803-5815, 1999.

Korolev, A., Emery, E., and Creelman, K.: Modification and tests of particle probe tips to mitigate effects of ice shattering, J. Atmos. Oceanic Technol., 30, 690-708, 2013a.

Korolev, A., Emery, E. F., Strapp, J. W., Cober, S. G., and Isaac, G. A.: Quantification of the effects of shattering on airborne ice particle measurements, J. Atmos. Oceanic Technol., 30, 25272553, 2013b.

Krämer, M. and Afchine, A.: Sampling characteristics of inlets operated at low U/U-0 ratios: new insights from computational fluid dynamics (CFX) modeling, J. Aerosol Sci., 35, 683-694, doi:10.1016/j.jaerosci.2003.11.011, 2004.

Liu, Y. S., Fueglistaler, S., and Haynes, P. H.: Advectioncondensation paradigm for stratospheric water vapor, J. Geophys. Res., 115, D24307, doi:10.1029/2010JD014352, 2010.

Mastenbrook, H. J. and Oltmans, S. J: Stratospheric Water Vapor Variability for Washington, DC/Boulder, CO: 1964-82, J. Atmos. Sci., 40, 2157-2165, doi:10.1175/15200469(1983)040<2157:SWVVFW>2.0.CO;2, 1983.

May, R. D.: Open-path, near-infrared tunable diode laser spectrometer for atmospheric measurements of $\mathrm{H}_{2} \mathrm{O}$, J. Geophys. Res. 103, 19161-19172, doi:10.1029/98JD01678, 1998. 
Perring, A. E., Schwarz, J. P., Gao, R. S., Heymsfield, A. J., Schmitt, C. G., Schnaiter, M., and Fahey, D. W.: Evaluation of a Perpendicular Inlet for Airborne Sampling of Interstitial Submicron Black-Carbon Aerosol, Aerosol Sci. Technol., 47, 1066-1072, doi:10.1080/02786826.2013.821196, 2013.

Peter, T., Marcolli, C., Spichtinger, P., Corti, T., Baker, M. B., and Koop, T.: When dry air is too humid, Science, 314, 1399-1402, doi:10.1126/science.1135199, 2006.

Popp, P. J., Gao, R. S., Marcy, T. P., Fahey, D. W., Hudson, P. K., Thompson, T. L., Kärcher, B., Ridley, B. A., Weinheimer, A. J., Knapp, D. J., Montzka, D. D., Baumgardner, D., Garrett, T. J., Weinstock, E. M., Smith, J. B., Sayres, D. S., Pittman, J. V., Dhaniyala, S., Bui, T. P., and Mahoney, M. J.: Nitric acid uptake on subtropical cirrus cloud particles, J. Geophys. Res., 109, D06302, doi:10.1029/2003JD004255, 2004.

Randel, W. J. and Jensen, E. J.: Physical processes in the tropical tropopause layer and their roles in a changing climate, Nat. Geosci., 6, 169-176, doi:10.1038/NGEO1733, 2013.

Rollins, A. W., Thornberry, T. D., Gao, R.-S., Hall, B. D., and Fahey, D. W.: Catalytic oxidation of $\mathrm{H}_{2}$ on platinum: a robust method for generating low mixing ratio $\mathrm{H}_{2} \mathrm{O}$ standards, Atmos. Meas. Tech., 4, 2059-2064, doi:10.5194/amt-4-2059-2011, 2011.

Rollins, A. W., Thornberry, T. D., Gao, R. S., Smith, J. B., Sayres, D. S., Sargent, M. R., Schiller, C., Krämer, M., Spelten, N., Hurst, D. F., Jordan, A. F., Hall, E. G., Vömel, H., Diskin, G. S., Podolske, J. R., Christensen, L. E., Rosenlof, K. H., Jensen, E. J., and Fahey, D. W.: Evaluation of UT/LS hygrometer accuracy by intercomparison during the NASA MACPEX mission, J. Geophys. Res., 119, 1915-1935, doi:10.1002/2013JD020817, 2014.

Rothman, L. S., Gordon, I. E., Barbe, A., Benner, D. C., Bernath, P. F., Birk, M., Boudon, V., Brown, L. R., Campargue, A., Champion, J.-P., Chance, K., Coudert, L. H., Dana, V., Devi, V. M., Fally, S., Flaud, J.-M., Gamache, R. R., Goldman, A., Jacquemart, D., Kleiner, I., Lacome, N., Lafferty, W.J., Mandin, J.-Y., Massie, S. T., Mikhailenko, S. N., Miller, C. E., Moazzen-Ahmadi, N., Naumenko, O. V., Nikitin, A. V., Orphal, J., Perevalov, V. I., Perrin, A., Predoi-Cross, A., Rinsland, C. P., Rotger, M., Simečkova, M., Smith, M. A. H., Sung, K., Tashkun, S. A., Tennyson, J., Toth, R. A., Vandaele, A.C., and Vander Auwera, J.: The HITRAN 2008 molecular spectroscopic database, J. Quant. Spec. Rad. Transf., 110, 533-572, doi:10.1016/j.jqsrt.2009.02.013, 2009.

Sargent, M. R., Sayres, D. S., Smith, J. B., Witinski, M., Allen, N. T., Demusz, J. N., Rivero, M., Tuozzolo, C., and Anderson, J. G.: A new direct absorption tunable diode laser spectrometer for high precision measurement of water vapor in the upper troposphere and lower stratosphere, Rev. Sci. Inst., 84, 074102, doi:10.1063/1.4815828, 2013.

Schiller, C., Krämer, M., Afchine, A., Spelten, N., and Sitnikov, N.: Ice water content of Arctic, midlatitude, and tropical cirrus, J. Geophys. Res., 113, D24208, doi:10.1029/2008JD010342, 2008.

Schoeberl, M. R. and Dessler, A. E.: Dehydration of the stratosphere, Atmos. Chem. Phys., 11, 8433-8446, doi:10.5194/acp11-8433-2011, 2011.
Sherwood, S. C. and Dessler, A. E.: A Model for Transport across the Tropical Tropopause, J. Atmos. Sci., 58, 765-779, doi:10.1175/1520-0469(2001)058<0765:AMFTAT>2.0.CO;2, 2001.

Solomon, S., Rosenlof, K. H., Portmann, R. W., Daniel, J. S., Davis, S. M., Sanford, T. J., and Plattner, G.-K.: Contributions of Stratospheric Water Vapor to Decadal Changes in the Rate of Global Warming, Science, 327, 1219-1223, 2010.

Thornberry, T. D., Rollins, A. W., Gao, R. S., Watts, L. A., Ciciora, S. J., McLaughlin, R. J., Voigt, C., Hall, B., and Fahey, D. W.: Measurement of low-ppm mixing ratios of water vapor in the upper troposphere and lower stratosphere using chemical ionization mass spectrometry, Atmos. Meas. Tech., 6, 1461-1475, doi:10.5194/amt-6-1461-2013, 2013.

Twohy, C. H., Schanot, A. J., and Cooper, W. A.: Measurement of condensed water content in liquid and ice clouds using an airborne counterflow virtual impactor, J. Atmos. Ocean. Technol., 14, 197-202, doi:10.1175/15200426(1997)014<0197:MOCWCI>2.0.CO;2, 1997.

Vömel, H., David, D. E., and Smith, K.: Accuracy of tropospheric and stratospheric water vapor measurements by the cryogenic frost point hygrometer: Instrumental details and observations, J. Geophys. Res., 112, D08305, doi:10.1029/2006JD007224, 2007.

Weinstock, E. M., Hintsa, E. J., Dessler, A. E., Oliver, J. F., Hazen, N. L., Demusz, J. N., Allen, N. T., Lapson, L. B., and Anderson, J. G.: New fast response photofragment fluorescence hygrometer for use on the NASA ER-2 and the Perseus remotely piloted aircraft, Rev. Sci. Inst., 65, 3544-3554, doi:10.1063/1.1144536, 1994.

Weinstock, E. M., Smith, J. B., Sayres, D., Spackman, J. R., Pittman, J. V., Allen, N., Demusz, J., Greenberg, M., Rivero, M., Solomon, L., and Anderson, J. G.: Measurements of the Total Water Content of Cirrus Clouds. Part I: Instrument Details and Calibration, J. Atmos. Ocean. Technol., 23, 1397-1409, 2006 a.

Weinstock, E. M., Smith, J. B., Sayres, D., Pittman, J. V., Allen, N., and Anderson, J. G.: Measurements of the Total Water Content of Cirrus Clouds. Part II: Instrument Performance and Validation, J. Atmos. Ocean. Technol., 23, 1410-1421, 2006 b.

Weinstock, E. M., Smith, J. B., Sayres, D. S., Pittman, J. V., Spackman, J. R., Hintsa, E. J., Hanisco, T. F., Moyer, E. J., St. Clair, J. M., Sargent, M. R., and Anderson, J. G.: Validation of the Harvard Lyman-? in situ water vapor instrument: Implications for the mechanisms that control stratospheric water vapor, J. Geophys. Res., 114, D23301, doi:10.1029/2009JD012427, 2009.

Zelinka, M. D. and Hartmann, D. L.: The observed sensitivity of high clouds to mean surface temperature anomalies in the tropics, J. Geophys. Res., 116, D23103, doi:10.1029/2011JD16459, 2011.

Zöger, M., Afchine, A., Eicke, N., Gerhards, M. T., Klein, E., McKenna, D. S., Mörschel, U., Schmidt, U., Tuitjer, F., Woyke, T., and Schiller, C.: Fast in situ hygrometers: A new family of balloon-borne and airborne Lyman alpha photofragment fluorescence hygrometers, J. Geophys. Res.-Atmos., 104, 1807-1816, doi:10.1029/1998JD100025, 1999. 